Egypt. Acad. J. Biolog. Sci., 13(1):9-16 (2020)

Egyptian Academic Journal of Biological Sciences

A. Entomology

ISSN 1687- 8809

http://eajbsa.journals.ekb.eg/

\title{
Biological Studies and Estimation Life Table Parameters of Chrysanthemum Aphid, Macrosiphoniella sanborni under Different Temperature Conditions
}

\author{
Samia, A. Yassin \\ Plant Protection Research Institute, A.R.C., Dokki, Giza, Egypt \\ Email: $\underline{\text { sabdelgawwad@su.edu.sa }}$
}

\begin{abstract}
ARTICLE INFO
ABSTRACT

Article History

Received:16/12/2019

Accepted:20/1/2020 laboratory conditions throughout three different temperatures degrees (winter, spring, and summer) during the 2018 year. Data obtained showed

Keywords: that the spring season more suitable for M. sanborni living (biology) more

Life table than winter and summer seasons, respectively. This showed clearly from the

parameters, Macrosiphoniella sanborni, temperatures

life table's parameters, which showed that the nymphal stages of M. sanborni in spring season were less than in winter and summer, respectively. Also, the life cycle, mean generation time, life span and longevity duration in spring season were less than in winter and summer seasons respectively. Lastly, the important parameter in the life table, intrinsic rate of increase (rm) in spring season was more than in winter and summer seasons, respectively.
\end{abstract}

\section{INTRODUCTION}

Chrysanthemum flowers consider one of the important cut flowers in Egypt and around all over the world. It is called (The Autumn flower) and sometimes called (The Autumn king). This because its flowers appear during autumn months (October- NovemberDecember). It is found from the oldest countries, it became one of the most popular flowers for people all over the world. This is due to their beautiful colors, style of flowers, tolerant of the inferable weather factors and possibility cultivation in different conditions both in open field and under greenhouse conditions.

Chrysanthemum flowers infested with a large scale of insects such as aphids insects and other insects groups. Macrosiphoniella sanborni (Gillette) consider one of the most dangerous insects, which infested chrysanthemum flowers both in open field and under glasshouse conditions, Ahmed and El-Deeb (2007). And Sumei, et al. (2015) reported that aphids and especially Chrysanthemum aphid $M$. sanborni have caused great damage to chrysanthemum production and affected seriously by the flowers both in quantity and quality under glasshouse conditions. Yanming, et al. (2010) found that Chrysanthemum aphid, $M$. sanborni represent the most destructive of chrysanthemum pests to cultivation and caused much damage to the flowers. Wang et al. (2016) reported that aphids have caused great damage to chrysanthemum production.

This study was carried out to study the biology and life table parameters of Chrysanthemum aphid, M. sanborni under laboratory conditions throughout three different temperatures degrees (winter, spring, and summer) during 2018 year. 


\section{MATERIALS AND METHODS}

This study was carried out to study the biology and life table parameters of Chrysanthemum aphid, Macrosiphoniella sanborni (Gillette) under laboratory conditions throughout three different temperatures degrees (winter, spring, and summer) during 2018 year, and this study was divided into three experiments:

In the first experiment, which was carried out during winter season, the mean daily temperature was $12.35 \pm 0.65^{\circ} \mathrm{C}$. that ranged from 11.37 to $13.45^{\circ} \mathrm{C}$. The mean relative humidity was $55.75 \pm 1.25 \%$ R.H. which ranged from 50.45 to $60.35 \%$ R.H.

At the second experiment, which was carried out during spring season, the mean daily temperature was $24.45 \pm 0.72{ }^{\circ} \mathrm{C}$, which ranged from 23.47 to $25.32^{\circ} \mathrm{C}$. The mean relative humidity was $65.22 \pm 1.75 \%$ R.H. which ranged from 60.25 to $70.65 \%$ R.H.

In the third experiment, which was carried out through summer season, the mean daily temperature was $33.49 \pm 0.74^{\circ} \mathrm{C}$, which ranged from 32.65 to $34.45^{\circ} \mathrm{C}$. The mean relative humidity was $75.45 \pm 1.65 \%$ R.H. which ranged from 70.35 to $80.65 \%$ R.H.

In each experiment apterous (mothers) were collected from chrysanthemum plants in the field, then thirty newly-borne progenies (first instar nymphs) resulted from these mothers were transferred separately using a fine hairbrush on discs of filter paper wetted with few water droplets inside thirty clean plastic Petri-dishes. The cover of these plastic Petri-dishes was replaced with muslin cover for good conditions of air and humidity. Fresh flowers of certain chrysanthemum plants were offered daily to each aphid for feeding.

Each group of nymphs was monitored daily until death and the following observations were made:

- Cast skin was removed regularly and periods elapsed between successive moults were recorded.

- The duration of the generation was recorded as time elapsed between birth and first parturition.

- The fraction of progeny reached maturity.

- Sex ratio was considered as one since all progeny developed to females.

- Survival of individuals throughout their developmental duration.

In the biological study trials, the obtained data of life table study was analyzed following Birch, L. (1948) using Life 48 Basic Computer Program (Abou-Setta et al., 1986).

\section{RESULTS AND DISCUSSION}

The present study was carried out to study the biology and life table parameters of Chrysanthemum aphid, Macrosiphoniella sanborni under laboratory conditions throughout three different temperatures degrees (winter, spring, and summer). This study was carried out during 2018 year and this study was divided into three experiments:

\section{The First Experiment (Winter Season):}

At the first experiment, which was carried out during winter season, the mean daily temperature was $12.35 \pm 0.65^{\circ} \mathrm{C}$, which ranged from 11.37 to $13.45^{\circ} \mathrm{C}$. The mean relative humidity was $55.75 \pm 1.25 \%$ R.H. which ranged from 50.45 to $60.35 \%$ R.H.

Data tabulated in Table (1) show life table parameters and statically analysis of $M$. sanborni during winter season (2018 year).

Data obtained from Table (1) show that the mean duration of the $1^{\text {st }}, 2^{\text {nd }}, 3^{\text {rd }}$ and $4^{\text {th }}$ instars were $1.83,1.86,1.81$ and 1.98 days, respectively, the Life cycle period was 8.39 days, while the mean generation time (T) was 15.23 days. The life span period was 15.35 days; the longevity duration was 10.64 days. The survival rate to maturity reached $67 \%$. The viviparity duration was 6.73 days. The net reproductive rate $\left(\mathrm{R}_{0}\right)$ and the intrinsic rate of increase $(\mathrm{rm})$ 
were 36.0 and 0.45 , respectively. The finite rate of increase (exp. rm) reached to 1.63 , while the generation doubling time was 2.80 days.

Table (1): Life table parameters of $M$. sanborni during winter season at $12.35 \pm 0.65^{\circ} \mathrm{C}$ and $55.75 \pm 1.25 \%$ R.H.

\begin{tabular}{|l|c|}
\hline \multicolumn{1}{|c|}{ Parameter } & Obtained value \\
\hline First instar (mean \pm sd) days & $1.83 \pm 0.65$ \\
\hline Second instar (mean \pm sd) days & $1.86 \pm 0.59$ \\
\hline Third instar (mean \pm sd) days & $1.81 \pm 0.45$ \\
\hline Fourth instar (mean \pm sd) days & $1.98 \pm 0.57$ \\
\hline Life cycle & $8.39 \pm 0.65$ \\
\hline Mean generation time (T) (days) & 15.23 \\
\hline Life span (days) & $15.35 \pm 0.85$ \\
\hline Longevity duration & $10.64 \pm 0.53$ \\
\hline Survival rate to maturity & $67 \%$ \\
\hline Viviparity duration (days) & $6.73 \pm 0.63$ \\
\hline Net reproductive rate $\left(\mathrm{R}_{0}\right)$ & 36 \\
\hline Intrinsic rate of increase (rm) & 0.45 \\
\hline Finite rate of increase (exp. rm) & 1.63 \\
\hline Generation doubling time (days)* & 2.80 \\
\hline (*) $=$ In 2/rm & \\
\hline Data are prest as & \\
\hline
\end{tabular}

Data are present as mean \pm sd

\section{Second Experiment (Spring Season):}

At the second experiment, which was carried out during spring season, the mean daily temperature was $24.45 \pm 0.72^{\circ} \mathrm{C}$, which ranged from 23.47 to $25.32^{\circ} \mathrm{C}$. The mean relative humidity was $65.22 \pm 1.75 \%$ R.H. which ranged from 60.25 to $70.65 \%$ R.H.

Data tabulated in Table (2) show life table parameters and statically analysis of $A$. durantae during spring season (2018 year).

Table (2): Life table parameters of $M$. sanborni during spring season at $24.45 \pm 0.72{ }^{\circ} \mathrm{C}$ and $65.22 \pm 1.75 \%$ R.H.

\begin{tabular}{|l|c|}
\hline \multicolumn{1}{|c|}{ Parameter } & Obtained value \\
\hline First instar (mean \pm sd) days & $1.65 \pm 0.45$ \\
\hline Second instar (mean \pm sd) days & $1.78 \pm 0.47$ \\
\hline Third instar (mean \pm sd) days & $1.69 \pm 0.42$ \\
\hline Fourth instar (mean \pm sd) days & $1.65 \pm 0.53$ \\
\hline Life cycle & $6.77 \pm 0.75$ \\
\hline Mean generation time (T) (days) & 12.52 \\
\hline Life span (days) & $14.36 \pm 0.84$ \\
\hline Longevity duration & $9.75 \pm 0.40$ \\
\hline Survival rate to maturity & $75 \%$ \\
\hline Viviparity duration (days) & $7.65 \pm 0.65$ \\
\hline Net reproductive rate $\left(\mathrm{R}_{0}\right)$ & 38 \\
\hline Intrinsic rate of increase (rm) & 0.65 \\
\hline Finite rate of increase (exp. rm) & 1.35 \\
\hline Generation doubling time (days)* & 2.35 \\
\hline (*) $=$ In $\mathbf{2} / \mathbf{r m}$ & \\
\hline
\end{tabular}

Data are present as mean \pm sd 
Data obtained from Table (2) show that the mean duration of the $1^{\text {st }}, 2^{\text {nd }}, 3^{\text {rd }}$ and $4^{\text {th }}$ instars were 1.65, 1.78, 1.69 and 1.65 days, respectively, the Life cycle period was 6.77 days, while the mean generation time ( $\mathrm{T}$ ) was 12.52 days. The life span period was 14.36 days; the longevity duration was 9.75 days. The survival rate to maturity reached $75 \%$. The viviparity duration was 7.65 days. The net reproductive rate $\left(\mathrm{R}_{0}\right)$ and the intrinsic rate of increase $(\mathrm{rm})$ were 38.0 and 0.65 , respectively. The finite rate of increase (exp. $\mathrm{rm}$ ) reached to 1.35 , while the generation doubling time was 2.35 days.

\section{Third Experiment (Summer Season):}

In the third experiment, which was carried out through summer season, the mean daily temperature was $33.49 \pm 0.74^{\circ} \mathrm{C}$, which ranged from 32.65 to $34.45^{\circ} \mathrm{C}$. The mean relative humidity was $75.45 \pm 1.65 \%$ R.H. which ranged from 70.35 to $80.65 \%$ R.H.

Data tabulated in Table (3) show life table parameters and statically analysis of $A$. durantae during summer season (2018 year).

Data obtained from Table (3) show that the mean duration of the $1^{\text {st }}, 2^{\text {nd }}, 3^{\text {rd }}$ and $4^{\text {th }}$ instars were $2.58,2.75,2.35$ and 2.75 days, respectively, the Life cycle period was 10.43 days, while the mean generation time (T) was 16.75 days. The life span period was 18.25 days; the longevity duration was 11.75 days. The survival rate to maturity reached $65 \%$. The viviparity duration was 5.75 days. The net reproductive rate $\left(\mathrm{R}_{0}\right)$ and the intrinsic rate of increase (rm) were 34.0 and 0.26 , respectively. The finite rate of increase (exp. rm) reached to 1.83 , while the generation doubling time was 3.75 days.

Comparison between Some Life Table Parameters of $M$. Sanborni at Different Temperatures Degrees (Winter, Spring, and Summer):

Data tabulated in Table (4) and Figures (1), (2), (3), (4), (5) and (6) show comparison between nymphal stages, life cycle, mean generation time, life span, longevity duration and intrinsic rate of increase $(\mathrm{rm})$ in the different temperatures degrees (winter, spring and summer). Obtained data show that the most seasons, which more suitable for M. sanborni living or biology was (spring, winter and summer), respectively.

Table (3): Life table parameters of $M$. sanborni during summer season at $33.49 \pm 0.74{ }^{\circ} \mathrm{C}$ and $75.45 \pm 1.65 \%$ R.H.

\begin{tabular}{|l|c|}
\hline \multicolumn{1}{|c|}{ Parameter } & Obtained value \\
\hline First instar (mean \pm sd) days & $2.58 \pm 0.45$ \\
\hline Second instar (mean \pm sd) days & $2.75 \pm 0.47$ \\
\hline Third instar (mean \pm sd) days & $2.35 \pm 0.55$ \\
\hline Fourth instar (mean \pm sd) days & $2.75 \pm 0.42$ \\
\hline Life cycle & $10.43 \pm 0.65$ \\
\hline Mean generation time (T) (days) & 16.75 \\
\hline Life span (days) & $18.25 \pm 0.35$ \\
\hline Longevity duration & $11.75 \pm 0.53$ \\
\hline Survival rate to maturity & $65 \%$ \\
\hline Viviparity duration (days) & $5.75 \pm 0.75$ \\
\hline Net reproductive rate $\left(\mathrm{R}_{0}\right)$ & 34 \\
\hline Intrinsic rate of increase (rm) & 0.26 \\
\hline Finite rate of increase (exp. rm) & 1.83 \\
\hline Generation doubling time $($ days) & $*$ \\
\hline ( $^{*}=$ In $2 /$ rm & 3.75 \\
\hline
\end{tabular}

Data are present as mean \pm sd 
This shows clearly from Table (4) whereas the nymphal stages period in spring was less than in winter and summer respectively. Also, the life cycle, mean generation time, life span and longevity periods in spring were less than in winter and summer respectively. Lastly, the essential parameter in biology comparison, intrinsic rate of increase (rm) (Birch, 1998) was more in spring season than its value in winter and summer respectively.

The obtained results are in agreement with those obtained by Emam (2009) who found that the nymphal stages (first instar, second instar, third instar and fourth instar) for Macrosiphum rosae on rose plants were 1.68, 1.36, 1.31 and 1.55 days, respectively. And life cycle, life span, generation time and longevity duration were 6.90, 15.36, 6.77 and 9.45 days, respectively. Mohamad and Al-Mallah (1987) studied the biology of the rose pest M. rosae under laboratory conditions in Mosul, Iraq. They found that generations varied significantly in terms of fecundity, duration of the nymphal stage and adult life span. There were 4 nymphal instars, of which the 1 st was the longest and the 2 nd the shortest. The intrinsic rate of natural increase $(\mathrm{rm})$ ranged from 0.25 to 0.63 . The $\mathrm{rm}$ values were similar under laboratory and field conditions. Bisht et al. (2010) found that the life cycle and life span period for Rose Aphid, M. rosae reached 7.43, 15,35 days, respectively. Kakar and Sood (2012) found on $M$. sanborni that the 4 nympha stages were completed in an average of 12.95 days in March and 12.70 days in November, and survival, adult lifespan and fecundity were higher in March than in November. On the other hand, Bisht et al., (2010) found that the subtropical and temperate climate, enforcing the sexual reproduction in the rose aphid, is favourable for the appearance of sexuales of M. rosaeiformis. Finally, Olmez et al., (2003) found that the developmental periods of immature stages ranged from 10.7 days at $17.5^{\circ} \mathrm{C}$ to 7.95 days at $25{ }^{\circ} \mathrm{C}$. The total percentages of survivorship of immature stages varied from 52.06 and $86 \%$ within the temperature range of $17.5-25^{\circ} \mathrm{C}$. The average longevity of adult females was $13.92,10.74,18.55$, and 8.65 days at $17.5,20,22.5$ and $25^{\circ} \mathrm{C}$, respectively. Mohsen and Hatami (2017) studied effect of temperature on some biological parameters of an Iranian population of the Rose Aphid, $M$. rosae and found that the degree $25^{\circ} \mathrm{C}$ is the most suitable degree for reproduction of it. Lastly, El-Nagar et al. (1990) who found that life cycle period for Rose Aphid, M. rosae ranged from 7-10 days.

Table (4): Comparison between nymphal stages, life cycle, mean generation time, life span, longevity duration and intrinsic rate of increase $(\mathrm{rm})$ in the different seasons: winter, spring and summer during 2018 year

\begin{tabular}{|l|c|c|c|}
\hline \multirow{2}{*}{\multicolumn{1}{|c|}{ Parameter }} & \multicolumn{3}{c|}{ Obtained value } \\
\cline { 2 - 4 } & Winter & Spring & Summer \\
\hline First instar (days) & 1.83 & 1.65 & 2.58 \\
\hline Second instar (days) & 1.86 & 1.78 & 2.75 \\
\hline Third instar (days) & 1.81 & 1.69 & 2.35 \\
\hline Fourth instar (days) & 1.98 & 1.65 & 2.75 \\
\hline Life cycle (days) & 8.39 & 6.77 & 10.43 \\
\hline Mean generation time (T) (days) & 15.23 & 12.52 & 16.75 \\
\hline Life span (days) & 15.35 & 14.36 & 18.25 \\
\hline Longevity duration (days) & 10.64 & 9.75 & 11.75 \\
\hline Intrinsic rate of increase (rm) & 0.45 & 0.65 & 0.26 \\
\hline
\end{tabular}




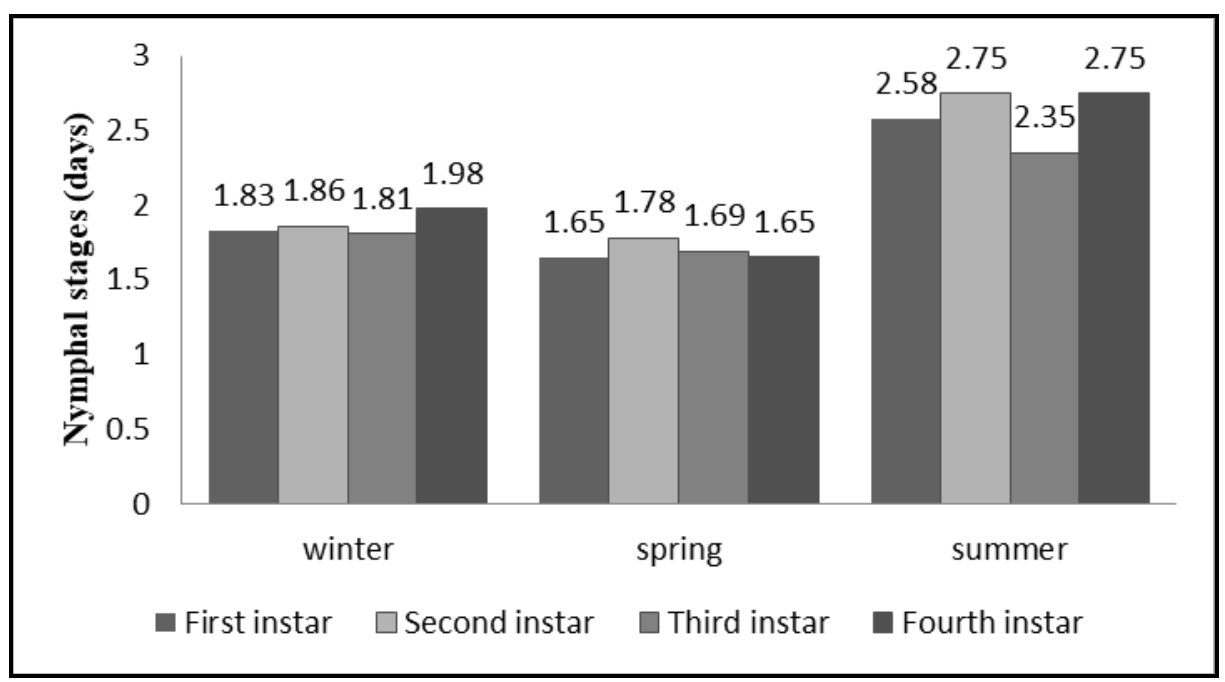

Fig. 1: Comparison between nymphal stages periods at winter, spring, and summer during

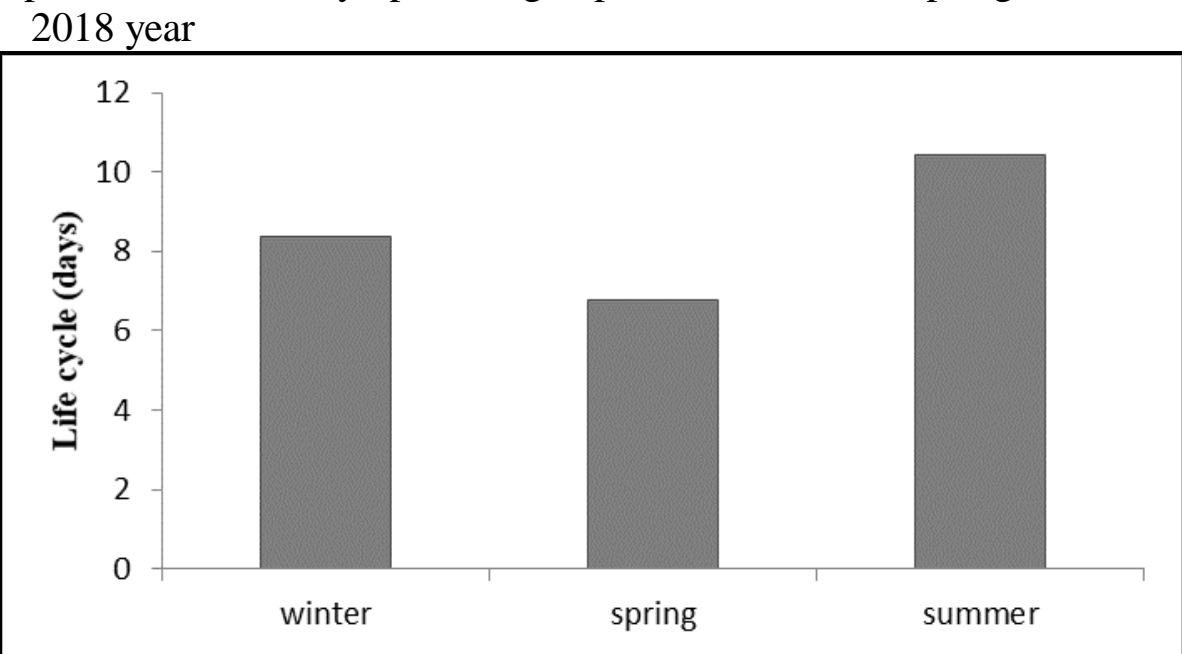

Fig. 2: Comparison between life cycle period in winter, spring and summer during 2018 year

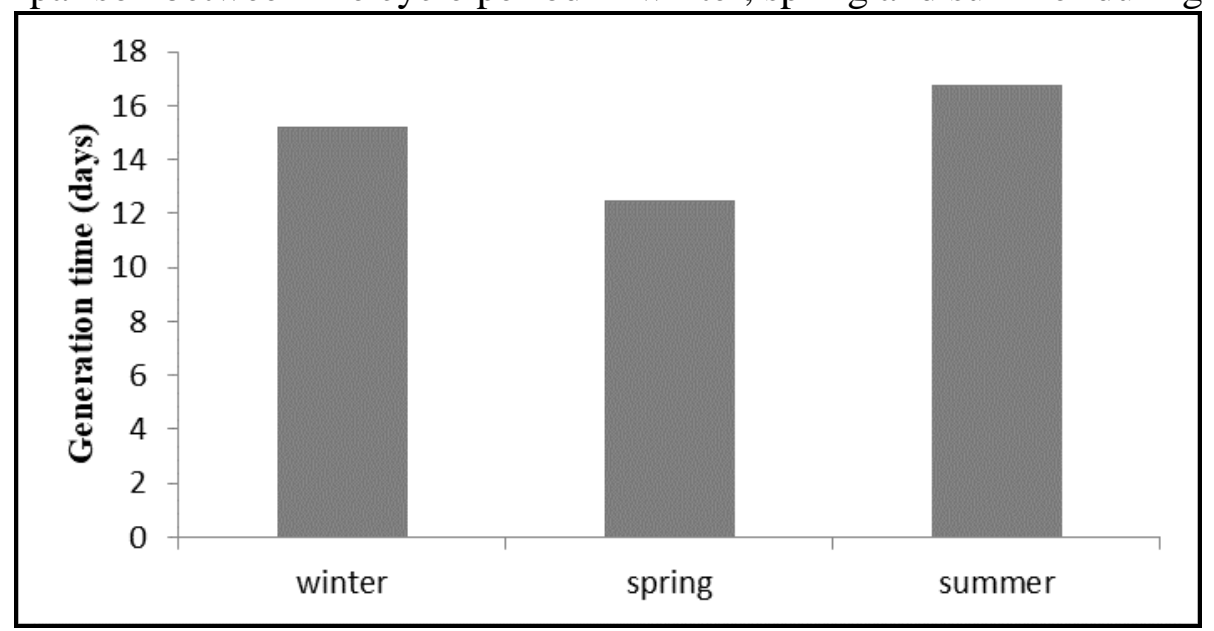

Fig. 3: Comparison between generation time in winter, spring and summer during 2018 year 


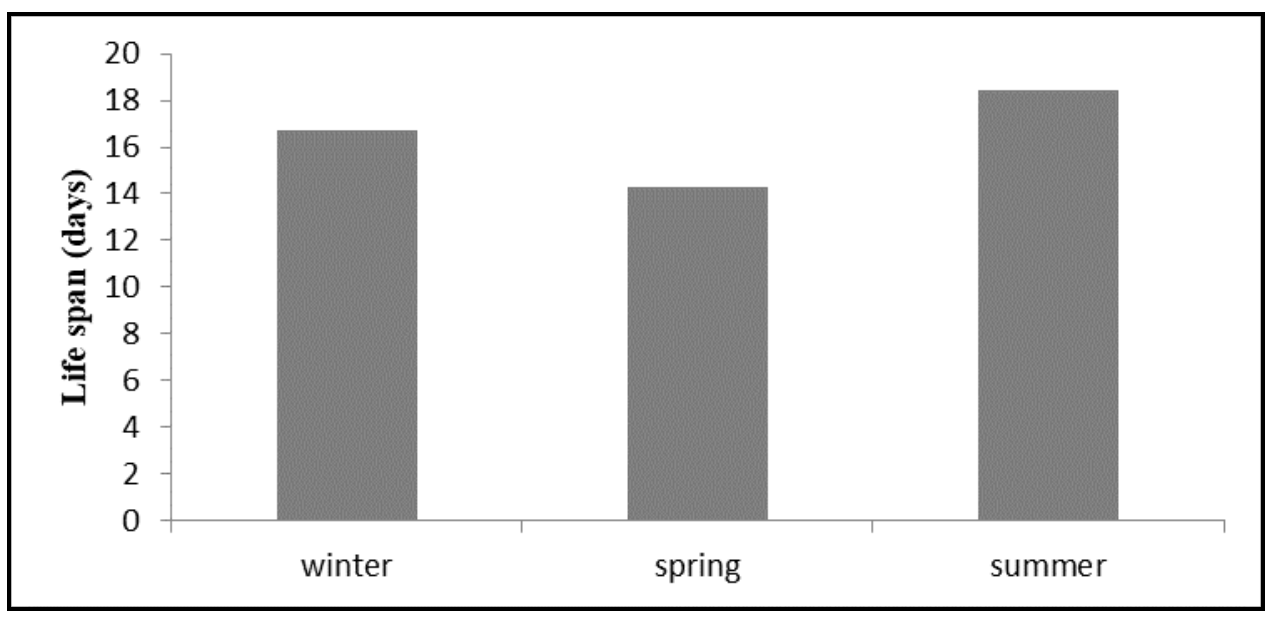

Fig. 4: Comparison between life span period in winter, spring and summer during 2018 year

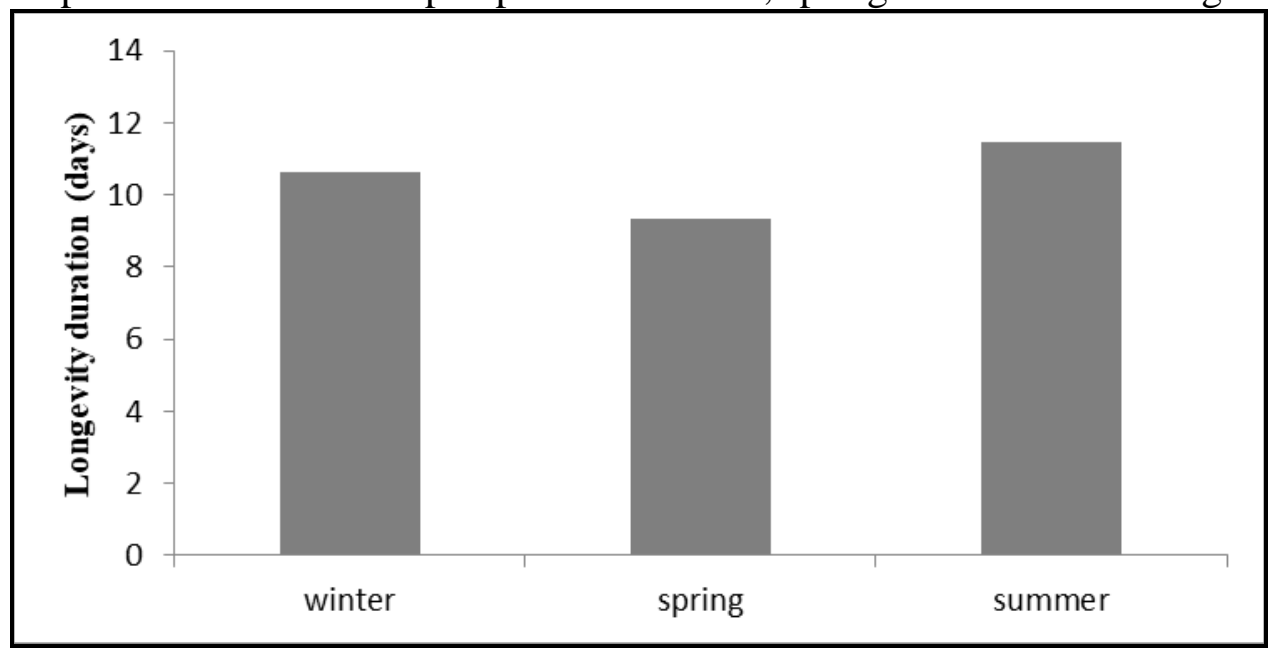

Fig. 5: Comparison between longevity period at winter, spring, and summer during 2018 year

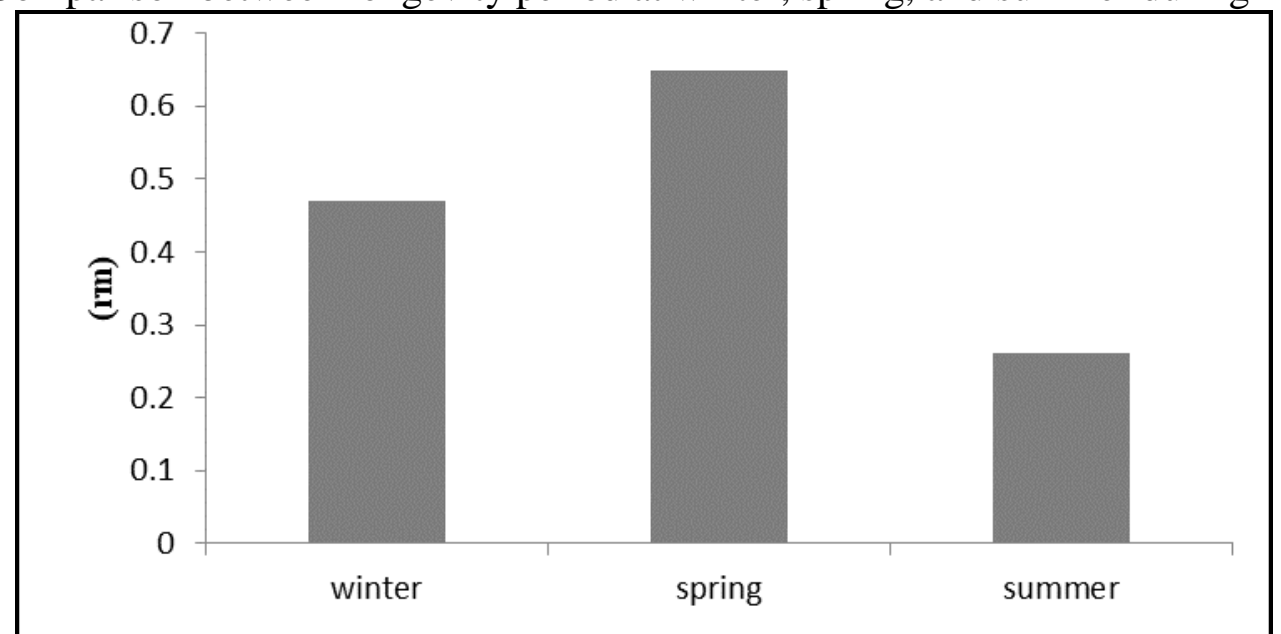

Fig. 6: Comparison between intrinsic rate of increase $(\mathrm{rm})$ at winter, spring and summer during 2018 year

\section{REFERENCES}

Abou-Setta, M. M.; Sorrel, R. W. and Childers, C. C. (1986). A basic computer program to calculate life table parameters for an insect or mite species. Florida Entomologist, 69 (4): 690 - 697.

Ahmed, S. and El-Deeb, M. (2007). Survey of abundant aphid species on common economic 
crops and wild plants in North Sinai Governorate, Egypt. Agricultural Research Journal, Suez Canal University 7(3), 129-132

Birch, L. C. (1998): The intrinsic rate of natural increase of an insect population. J. Anim. Ecol., 17: 15-26

Bisht, R. S.; Rana, D. S. and Mishra, P. N. (2010). Biology of the rose aphid Macrosiphum rosae (Homoptera: Aphididae). Anal. Plant Prot. Sc.9 (2): 186-195.

El-Nagar, S.; Ismail, A. and Attia, A. (1990). The biology of the Rose Aphid, M. rosae. Bulletin de la Societe Entomologigue d Egypt, 64:161-172

Emam, A. S. (2009). Effect of insect infestation on some rose plants. Thesis of PhD. Fac. Agric. Al-Azhar Univ.

Kakar, K. L. and Sood, A. K. (2012). Biological studies and control of rose aphid, Macrosiphum rosae. Journal of Aphidology, 3(1): 113-118.

Mohamad, M. A. and Al-Mallah, N. M. (1987). Ecological and biological studies on the rose aphid, Macrosiphum rosae (L.) (Homoptera, Aphididae) in Mosul region. Arab J. Plant Prot. 5(2):53-58

Mohsen, M. and Hatami, B. (2017). Effect of temperature on some biological parameters of an Iranian population of the Rose Aphid, Macrosiphum rosae (Hemiptera: Aphididae). European Journal of Entomology. 104(3): 235-245

Olmez, S.; Bayhan, E. and Ulusoy, M. R. (2003). Effect of different temperatures on the biological parameters of Macrosiphum rosae (L.) (Homoptera: Aphididae). Zeitschriftfur- Pflanzenkrankheiten- und- Pflanzen- schutz, 110(2): 203- 208

Sumei, W.; Fei, Z. and Zhiyong, G. (2015). Inheritance and molecular markers for aphid (Macrosiphoniella sanbourni) resistance in chrysanthemum (Chrysanthemum morifolium). Scientia Horticulturae 180, 220-226

Wang, C.; Zhang, F. and Guan, Z. (2016). Inheritance and molecular markers for aphid (Macrosiphoniella sanborni) resistance in chrysanthemum (Chrysanthemum morifolium Ramat.). Scientia Horticulturae 180, 220-226

Yanming, D. ; Sumei, C.; Aimin, L. and Fadi, C.(2010). Production and characterization of the intergeneric hybrids between Dendranthema morifolium and Artemisia vulgaris exhibiting enhanced resistance to chrysanthemum aphid. Planta 231 (3), 693-703

\section{ARABIC SUMMARY \\ دراسات بيولوجية وتقدير قياسات جدول الحياة لحشرة من الكريزانثيم Macrosiphoniella sanborni تحت ظروف درجات الحرارة المختلفة من الثرئة

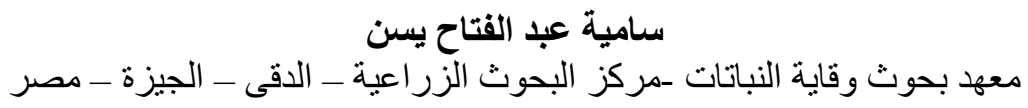

أجريت هذه الدراسة بغرض دراسة دورة الحياة (بيولوجية) حشرة من الكريز انثيمم Macrosiphoniella sanborni (Gillette)

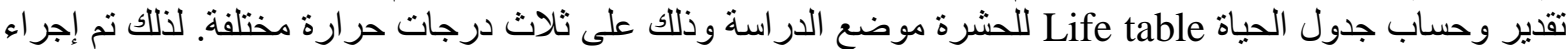

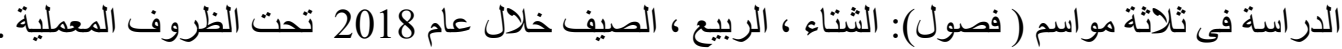

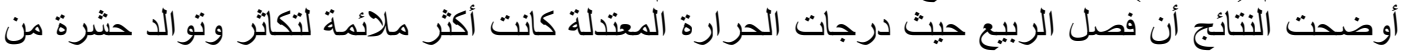

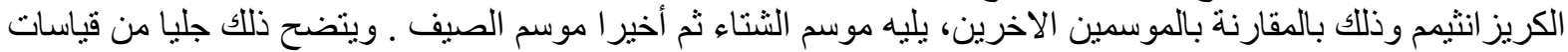

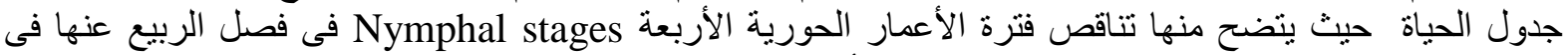

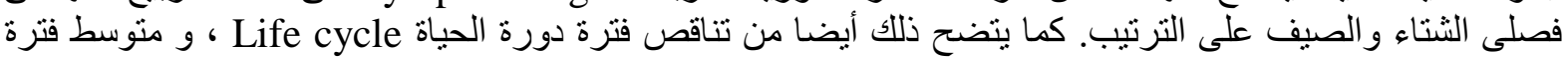

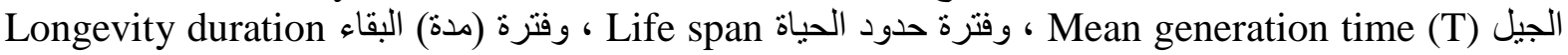
فى موسم الربيع عنها فى موسمى الثناء و الصيف على التى الترتيب.

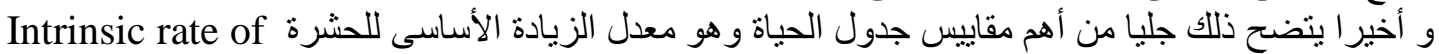
increase (rm) 